\title{
EXPERIMENTAL STUDY OF HIGH VOLUME FLY ASH IN CONCRETE
}

\author{
Gaddam Dinesh ${ }^{1}$, Nitesh kumar Sah $^{2}$
}

\begin{abstract}
Concrete is the primary requirement for construction of any structure and hence is listed as the world's second most used material. Cement is the only binding material in the conventional concrete whose production causes emission of large amount of greenhouse gases like $\mathrm{CO}_{2}$ which leads to Global Warming. Hence, in order to overcome these problem, cement can be partially replaced by the by-product of power plant's fly ash which also has binding property like cement its production is more economical, sustainable and eco-friendly. There are number of advantages of using fly ash in concrete to increase strength parameters in structures. The chief goal of the present investigation is to study mechanical behaviour of the HVFAC. In this study, the behaviour are studied with various partial replacements of cements like 30\%, 40\%, 50\%, 60\%.In contrast to conventional concrete, 50\% replacement showed overall equal strength in 28 days. The results are taken for 7 and 28 days.
\end{abstract}

Keywords: HVFAC, MasterGlenium Ace 30

\section{INTRODUCTION}

Concrete is considered to be the second most used material in the world. The components of the concrete are FA, CA, cement, water. The vital environmental problems related with cement production are utilization of raw materials, large amount of energy and releasing of air. The third largest producer of anthropogenic after transport and energy generation in the entire world is cement production. $\mathrm{CO}_{2}$ is one of the major greenhouse gas which causes Global Warming.

In addition to there, the cement dust is one of the causative agent for various diseases like lung function impairment, chronic obstructive lung diseases, stomach and colon. It also effects plants. Moreever its' expensive too. Keeping these bad impacts of cement production of cost, utilization of large amount of energy and resource, various replacements include fly ash, GGBs, silica, fume, rice husk ash metakaolin, etc. The use of these products improves the properties of concrete.

According to the American Concrete Institution (ACI) Committee $116 \mathrm{R}$, fly ash is defined as, "the finely divided residue the results from the combustion of ground and powdered coal and that is transported by five gases from combustion zone to particle removal system". Which is removed either mechanically or using electrostatic precipitation. Similar to cement, fly ash also acts as binding material. Fly ash can be used in order to increase strength, utilize the surplus by-product and reduce cost of construction and overcome most of the problems that arises due cement production. On the other hand, the problem of disposal of the fly ash is too solved.

\section{RELATED STUDIES}

The past studies on HVFAC reveals that the replacement of cement by fly ash in concrete made great changes in properties such as reduction in cost, significant reduction of steel corrosion, minimization of potential alkali aggregate reaction, reduction in heat of hydration, improvement in durability of concrete etc. $[1,2,3,4,5]$ In addition, it improves the environment by contributing towards reduction of greenhouse gases [6].

\section{MATERIALS USED}

\subsection{Cement}

The Ordinary Portland Cement "PENNA" of 53 grade is used specifying all the properties from IS12269-1987. The fineness modulus and sp. Gravity of the cement were found to be $5.3 \%$ and 3.159 respectively.

\subsection{Coarse Aggregate}

$20 \mathrm{~mm}$ and $10 \mathrm{~mm}$ coarse aggregate are selected by passing the aggregate through $20 \mathrm{~mm}$ and $10 \mathrm{~mm}$ sieves respectively. Particle shape of both the aggregate is angular. The sp. Gravity and fineness modules of CA were 2.83 and $8 \%$ respectively.

\subsection{Fine Aggregate}

Natural Sand is selected as fine aggregate. Sand is sieved from $4.75 \mathrm{~mm}$ sieve and also washed to reduce the silt content.The sp. Gravity and fineness modules of sand were found to be 2.70 and $2.9 \%$ respectively.

\subsection{Super Plasticizers}

Master Glenium ACE 30 (JP) is an admixture of new generation based on second-generation polycarboxylic Etherpolymer with high early strength gains. It is free of 
chloride \& low alkali. It's compatible with all kinds of cements. Its specific gravity is 1.09. It is grey liquid and helps in obtaining earlier development of heat of hydration, rapid strength development of the hydration product as a consequence, higher strength at early stage. Some special features are:

- Achieve high early strengths.

- Optimize curing cycles by reducing curing time or curing temperatures.

- Eliminate heat curing.

- Eliminate the energy required for placing, compacting \& curing (Zero Energy System).

- Increase productivity/ reduction in cycle time.

- Improve surface appearance.

- $\quad$ Produce durable precast concrete elements.

\subsection{Water}

Portable water, available in laboratory, is used for mixing and curing of concrete. Water is free from unwanted substances and chemical oxides.

\subsection{Fly Ash}

It is collected from NTPC Thermal Power Plant, Visakhapatnam. The class is class $\mathrm{F}$ with specific gravity 2.21 .

\section{MIX PROPORTION}

The mixed proportions is fixed to selection suitable ingredient of concrete and determine their relative amounts with the objective of producing a concrete of required strength, durability and workability as economical as possible. The obtained mix proportion should be good enough to fulfil the criteria of plastic and hardened concrete. If the plastic concrete is not required consistency for floating, it can't be placed and compacted properly.M30 mix is designed based on guidance given by IS10262:2009. In the absolute calculation of mixed proportion, the proportion of the volume Cementous material to FA and CA is calculated for $1 \mathrm{~m}^{3}$ of concrete first. In the present circumstances, the space occupied by air is considered as zero. The design proportion is for obtaining slump value of $75 \mathrm{~mm}$.

Number of trial mixes are made with 30\%, 40\%,50\%, 60\% replacement of cement by fly ash.

\begin{tabular}{|c|c|c|}
\hline Designation & M0 & M1 \\
\hline \%Fly ash & $0 \%$ & $30 \%$ \\
\hline $\operatorname{Cement}\left(\mathrm{Kg} / \mathrm{m}^{3}\right)$ & 370 & 283 \\
\hline Fly $\operatorname{ash}\left(\mathrm{Kg} / \mathbf{m}^{3}\right)$ & 0 & 122 \\
\hline $\begin{array}{l}\text { Fine aggregate } \\
\left(\mathrm{Kg} / \mathrm{m}^{3}\right)\end{array}$ & 737.69 & 703 \\
\hline $\begin{array}{l}\text { Coarse aggregate } \\
\left(\mathrm{Kg} / \mathrm{m}^{3}\right)\end{array}$ & 1261.55 & 1204 \\
\hline $\begin{array}{l}\text { Super Plasticizer } \\
\left(\mathrm{Kg} / \mathrm{m}^{3}\right)\end{array}$ & 1.85 & 2.02 \\
\hline Water & 163 & 158 \\
\hline
\end{tabular}

\section{EXPERIMENTAL METHOD}

The coarse aggregate was kept completely immersed in clean water for 24 hours for water absorption. After 24 hours, the aggregate was gently surface dried. It was then spread out and exposed to the atmosphere until it appears to be completely surface dry. For fine aggregate, considering the huge time to be taken to become surface dry from wet condition, it was not immersed in water. Instead the water was sprinkled then it was spread out and exposed to the atmosphere until it appears to be completely surface dry.

Weight batch method is adopted to measure the quantities. The quantities of fine aggregate, Natural coarse aggregate, super plasticizer, cement, water for each batch were measured by a weighing balance according to the mix proportions obtained by the mix design. Then the aggregates were mixed thoroughly. The cubes and cylindrical moulds of cast iron were taken. The standard sizes of cube moulds were $150 \mathrm{~mm} * 150 \mathrm{~mm} * 150 \mathrm{~mm}$ and cylindrical moulds of $150 \mathrm{~mm}$ diameter and $300 \mathrm{~mm}$ height. Oil were applied properly in the inner faces of the moulds and after thorough mixing of concrete ingredients, they were casted into the cubes and cylinders by proper compaction. Compaction was done in three layes, each layer compacted by using tamping rods 25 blows. The prepared concrete specimens were left for 24 hours and then taken out of moulds and cured in water. When the curing period of 7 and 28 days were over for the respective cubes and cylinders, the cubes were tested for compressive strength and cylinders for split tensile strength.

\section{STUDY SURVEY}

\subsection{Slump Test}

The concrete slump test is used for the measurement of a property of fresh concrete. The test is an empirical test that measures the workability of fresh concrete. More specifically, it measures consistency between batches. The test is popular due to the simplicity of apparatus used and simple procedure. The results are shown in Table 2 and Figure 1.

\subsection{Compaction Factor Test}

Compacting factor of fresh concrete is done to determine the workability of fresh concrete by compacting factor test as per IS: 1199 - 1959. The apparatus used is Compacting factor apparatus. The results are shown in Table 3 and Figure 2.

\subsection{Compressive Strength Test}

Compressive strength of concrete depends on many factors such as water-cement ratio, cement strength, quality of concrete material, quality control during production of concrete etc. Test for compressive strength is carried out either on cube or cylinder. American Society for Testing Materials ASTM C39/C39M provides Standard Test Method for compressive strength of concrete. The results are shown in Table 4 and Figure 3. 


\subsection{Split Tensile Strength}

It is the standard test, to determine the tensile strength of concrete in an indirect way. This test could be performed in accordance with IS:5816-1970. A standard test cylinder of concrete specimen (300 $\mathrm{mm} \mathrm{X} \mathrm{150mm} \mathrm{diameter)} \mathrm{is} \mathrm{placed}$ horizontally between the loading surfaces of Compression Testing Machine with wooden supports. The results are shown in Table 5 and Figure 4.

\section{RESULTS AND DISCUSSION}

\subsection{Slump Test}

Table 2: slump Cone Test Result

\begin{tabular}{|l|l|}
\hline$\%$ of fly ash & Slump in $\mathrm{mm}$ \\
\hline $0 \%$ & 65 \\
\hline $30 \%$ & 63 \\
\hline $40 \%$ & 68 \\
\hline $50 \%$ & 71 \\
\hline $60 \%$ & 73 \\
\hline
\end{tabular}

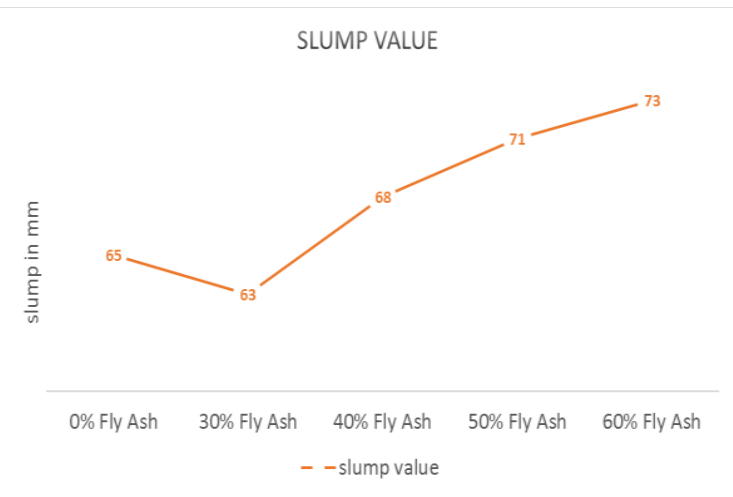

Fig.1 Slump value

\subsection{Compaction Factor Test}

Table 3: Compaction Factor Test Results

\begin{tabular}{|l|l|}
\hline$\%$ of fly ash & Compaction factor \\
\hline $0 \%$ & 0.86 \\
\hline $30 \%$ & 0.85 \\
\hline $40 \%$ & 0.87 \\
\hline $50 \%$ & 0.87 \\
\hline $60 \%$ & 0.9 \\
\hline
\end{tabular}

\section{COMPACTION FACTOR}

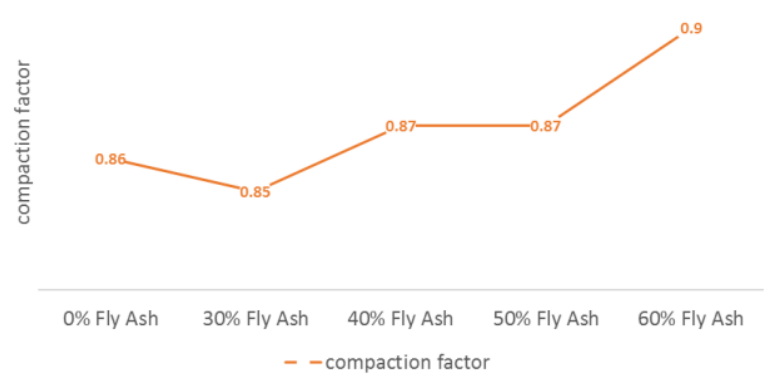

Fig 2: Compaction Factor value

\subsection{Compressive Strength Test}

Table 4: Compressive Strength Variations with Various Mixes

\begin{tabular}{|l|l|l|}
\hline$\%$ of fly ash & 7 days strength & 28 days strength \\
\hline $0 \%$ & 31.20 & 45.48 \\
\hline $30 \%$ & 21.56 & 34.78 \\
\hline $40 \%$ & 23.28 & 36.89 \\
\hline $50 \%$ & 25.71 & 39.68 \\
\hline $60 \%$ & 18.71 & 27.84 \\
\hline
\end{tabular}

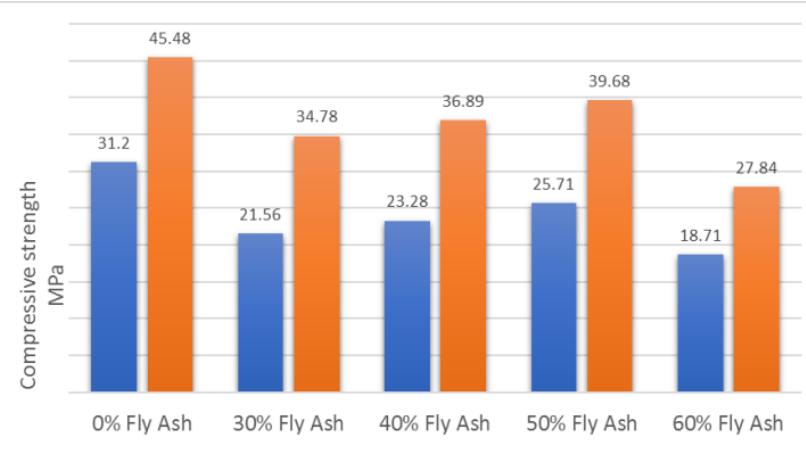

Fig 3: Compressive strength Results

\subsection{Split Tensile Strength Test}

Table 5: Split Tensile Strength Variations with Various

\begin{tabular}{|l|l|}
\multicolumn{2}{c}{ Mixes } \\
\hline $0 \%$ & 28 days strength \\
\hline $30 \%$ & 4.31 \\
\hline $40 \%$ & 2.63 \\
\hline $50 \%$ & 2.54 \\
\hline $60 \%$ & 2.19 \\
\hline
\end{tabular}

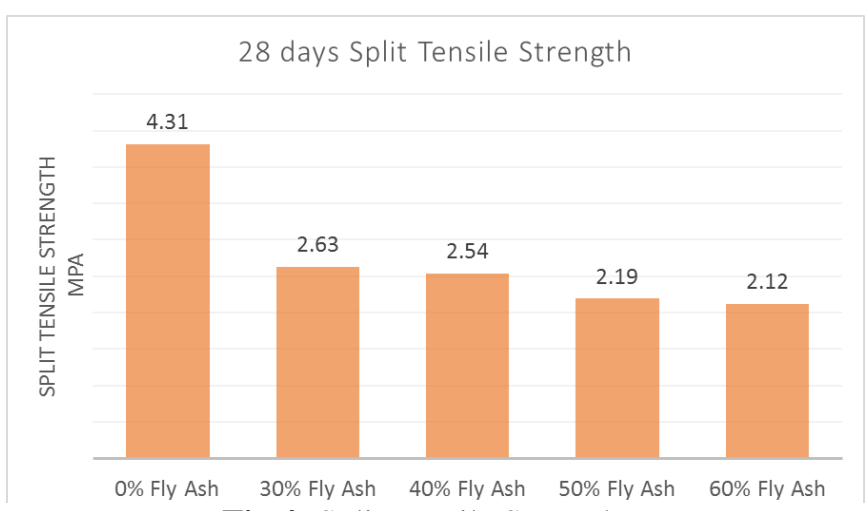
Fig 4: Split Tensile Strength

\section{CONCLUSION}

- Addition of fly ash improves the workability of concrete.

- Addition of 50\% fly ash reduces 7day strength by about $20 \%$ when compared to control mix. But it acquires strength almost equal to that of control mix at 28 days and attained higher strength thereafter.

- All hardened properties are similar for OPCC and HVFAC at 28 days. 
- Cost comparison reveals that site mixed OPC with $50 \%$ fly ash concrete is $24 \%$ cheaper than OPC concrete.

- The strength of concrete with $40 \%, 45 \%$, and $50 \%$ fly ash content, even at 28 days is sufficient enough for use in reinforced cement concrete construction.

- The concrete containing 50\% fly ash developed high strength, while $60 \%$ fly ash replacement concrete developed moderate strength.

- The study proved that it is possible to convert an RCC (zero slump) concrete to a workable concrete with the use of a suitable superplasticizer

- Better cost economy due to lower material cost and highly favourable lifecycle cost.

- With its high strength properties, HVFA roller compacted concrete becomes a possible alternative to NPC concrete used for road pavements applications and large industrial floors.

\section{REFERENCES}

[1]. AnilBanchhor and S. Krishnan, "Evaluating the effectiveness of fly ash incorporation as PPC vis-à-vis separated addition to the site-mixed OPC Concrete". The Indian Concrete Journal, April 2006, pp. 17-26.

[2]. Mehta, P.K. "Durability: Critical Issues for the Future." Concrete International 19(7), 1997, pp. 69-76.

[3]. Mullick.A.K, "Use of fly ash in structural concrete: Part I -Why?"- The Indian concrete Journal, May 2005, pp. 1322.

[4]. Malhotra, V.M., and P.K. Mehta. High-Performance, High-Volume Fly Ash Concrete. Supplementary Cementing Materials for Sustainable Development, Inc., Ottawa, Canada, 2002, $101 \mathrm{pp}$

[5]. Mullick.A.K, "Use of fly ash in structural concrete: Part II -How much?"- The Indian concrete Journal, June 2005, Vol79, No.6, pp. 10-14.

[6]. Prabhakar.J, P.DevadasManoharan and M. Neelamegam, "Effect of fly ash on durability and performance of concrete", November 2011, pp. 915.

[7]. Deepak Juneja, "High Volume Flyash Concrete for the Reduction of Greenhouse Gases". - CE \&CR Feb2009, pp. 34-43.

[8]. Malhotra, V.M., and P.K. Mehta. High-Performance, High-Volume Fly Ash Concrete. Supplementary Cementing Materials for Sustainable Development, Inc., Ottawa, Canada, 2002, $101 \mathrm{pp}$

[9]. M S Shetty (2008), Concrete Technology, S Chand Publication House

[10]. M L Gambhir, Concrete Technology, Tata McGrawHill Book, New York.

\section{BIOGRAPHIES}

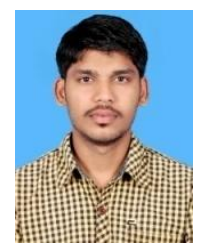

GADDAM DINESH, M.Tech. [Housing planning]

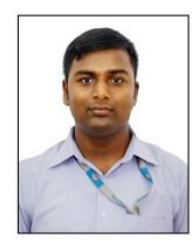

NITESH KUMAR SAH 